RECOLLECTIONS OF A REVOLUTION 
Also from St. Martin's Press

The Arena of Capital

Michael Dunford and Diane Perrons

Geography and the State

R. J. Johnston 


\title{
Recollections of a Revolution
}

Geography as Spatial Science

\author{
edited by \\ Mark Billinge, Derek Gregory and \\ Ron Martin
}


(C) Part I Mark Billinge, Derek Gregory and Ron Martin 1983

(C) Parts II and III The Macmillan Press Ltd 1983

ISBN 978-0-333-27149-0

ISBN 978-1-349-17416-4 (eBook)

DOI 10.1007/978-1-349-17416-4

Softcover reprint of the hardcover 1st edition 1983

All rights reserved. For information, write:

St. Martin's Press, Inc., 175 Fifth Avenue, New York, NY 10010

First published in the United States of America in 1984

ISBN 978-0-312-66587-6

\section{Library of Congress Cataloging in Publication Data}

Main entry under title:

Recollections of a revolution.

Includes index.

1. Geography-Philosophy-Addresses, essays, lectures.

I. Billinge, Mark. II. Gregory, Derek. III. Martin,

R. L. (Ron L.)

C70.R43 1984

ISBN 978-0-312-66587-6

$910^{\prime} .01 \quad 83-19191$




\section{Contents}

Preface

vii

List of Contributors

Part I Reconstructions

by Mark Billinge, Derek Gregory and Ron Martin

\section{Part II Recollections}

Experiences of an Outside Man

by Harold C. Brookfield

A Foundling Floundering in World Three

by R. J. Johnston

Recollections of the "Quantitative Revolution's" Early Years:

The University of Washington 1955-65

by Richard L. Morrill

Toward a Sermon of Modernity

by Gunnar Olsson

From Here and Now to There and Then: Some Notes on

Diffusions, Defusions and Disillusions by Allan Pred

A Pleasant Pain by Brian T. Robson

Recollections of a Random Variable by David M. Smith

Trajectories and Co-ordinates

by William Warntz

\section{Part III Reflections}

Unmasking Technocratic Geography by David Mercer 


\section{vi Contents}

One Man's Quantitative Geography: Frameworks, Evaluations, Uses and Prospects

by Alan G. Wilson

200

Index

227 


\section{Preface}

The Critical Human Geography series has as one of its central concerns the construction of a genuinely human geography, and this means (in part) recognizing that its concepts are specifically human constructions, historically rooted in particular social formations, and capable of - demanding of - continuous examination and criticism. This volume of essays has therefore been conceived to illustrate the importance of human agency in scientific change: to provide materials which illuminate both the boundedness and the contingency of research traditions and transformations in geography. Although it is concerned with a major episode in the evolution of post-war geography, the so-called "quantitative revolution" which began to convulse the discipline in the 1950s and 1960s, it is in no sense a manifesto. We have provided no detailed commentary on the achievements of spatial science, and although the critique of positivist and post-positivist philosophy and the emergence of a neo-quantitative movement are important moments for critical inquiry that debate is more usefully conducted elsewhere. But we believe that the accounts which follow vitiate any representation of "progress in geography" as an autonomous, disembodied process with its own internal, inexorable "logic"; it is, rather, a history in which we are all implicated, and for which we are all in some measure responsible. And it is for this reason as much as any other that we have chosen not to offer any arguments of our own. To do so would be to impose, however tacitly, a pre-formed structure on to the text, whereas we prefer to engage its readers in a much more open (and, we hope, a much more honest) dialogue with the historical constitution of contemporary geography. The debate is in no sense closed around a privileged circle of participants.

In Part I, “Reconstructions", we provide some outline comments on the ways in which a history of geography might be written, and on the overall course of the "quantitative revolution". These are intended to act as a counterpoint to the essays gathered together in Part II, "Recollections", where a number of writers record their own experiences of those busy decades. There is no great mystery about their selection, and we do not claim that our sample is in any 


\section{viii Preface}

way representative. But all of these contributors readily accepted our invitation to write a short, autobiographical essay - many more did not - and their willingness to submit these private accounts to public scrutiny displays a collective generosity without which academic exchange would be utterly impoverished. Finally, Part III, "Reflections", allows two authors to assess the impact and implications of spatial science from radically opposing perspectives, and to underscore the various ways in which the histories recorded in these pages are not closed around past or present, but resonate into all our futures.

We are deeply grateful to all of these contributors for their cooperation.

University of Cambridge, England

Mark Billinge

Derek Gregory

Ron Martin 


\section{List of Contributors}

Contributors' names appear in order of appearance.

Mark Billinge is Fellow of Magdalene College and Lecturer in the Department of Geography, University of Cambridge.

Derek Gregory is Fellow of Sidney Sussex College and Lecturer in the Department of Geography, University of Cambridge.

Ron Martin is Fellow of St Catharine's College and Lecturer in the Department of Geography, University of Cambridge.

Harold C. Brookfield is Professor in the Research School of Pacific Studies, Department of Human Geography, Australian National University.

R.J. Johnston is Professor in the Department of Geography, University of Sheffield.

Richard L. Morrill is Professor in the Department of Geography, University of Washington.

Gunnar Olsson is Professor in the Nordiska instituet for samhällsplanering, Skeppsholmen, Stockholm.

Allan Pred is Professor in the Department of Geography, University of California, Berkeley.

Brian T. Robson is Professor in the Department of Geography, University of Manchester.

David M. Smith is Professor in the Department of Geography, Queen Mary College, University of London.

William Warntz is Professor in the Department of Geography, University of Western Ontario.

David Mercer is Senior Lecturer in the Department of Geography, Monash University, Melbourne.

Alan G. Wilson is Professor in the School of Geography, University of Leeds. 